\title{
Pemberian Legal Standing kepada Perseorangan atau Kelompok Masyarakat dalam Usul Pembubaran Partai Politik
}

\author{
Allan Fatchan Gani Wardhana \& Harry Setyanugraha \\ Mahasiswa Fakultas Hukum Universitas Islam Indonesia \\ Jl. Taman Siswa No. 158 Yogyakarta \\ allanfatchanganiw@yahoo.com; harrysetyanugraha@gmail.com
}

\begin{abstract}
Political party and corruption in Indonesia can be allegorized as two sides of a coin, both of which relate closely to each other. Law No. 2 of 2008 in conjunction with Law No. 2 of 2011 on Political Party mentions one of the reasons of the political party dismissal, namely conducting an activity which violates the regulations of law. The proposition to dismiss a political party comes only from the Government. This fact closes the opportunity of other parties like individual or community group to propose a political party dismissal. The problems studied in this research are: First, the reason why an individual or a community group should be given the legal standing in the proposition of the political party dismissal. Second, the relevance of the legal standing provision to an individual or a community group in the proposition of the political party dismissal. Third, what attempt that can be conducted to provide the legal standing for an individual or a community group in the proposition of the political party dismissal. The method used in this research is normative juridical method employing law material approach. The result of the research concludes that: First, the urgency to provide the legal standing for an individual or a community group in the proposition of the political party dismissal to interpret the implementation of the people sovereignty in the law state principle. Second, by the provision of legal standing for an individual or a community group, the citizen monitoring toward the political parties will be more effective. Third, the attempt that can be conducted to provide legal standing for an individual or a community group in the provision of the political party dismissal is by revising the Constitutional Court Law.
\end{abstract}

Key words : Individual or community group, legal standing, dismissal, political party.

\begin{abstract}
Abstrak
Partai politik dan korupsi di Indonesia bisa diibaratkan dua sisi mata uang, keduanya memiliki hubungan yang cukup erat. Undang-Undang No. 2 Tahun 2008 jo. Undang-Undang No. 2 Tahun 2011 tentang Partai Politik menyebutkan salah satu alasan pembubaran partai politik adalah melakukan kegiatan yang bertentangan dengan undang-undang. Usul pembubaran partai politik hanya diberikan kepada Pemerintah. Hal ini jelas menutup pihak lain seperti perseorangan atau kelompok masyarakat untuk dapat mengusulkan pembubaran partai politik. Penelitian ini mengkaji permasalahan: pertama, alasan perseorangan atau kelompok masyarakat perlu diberikan legal standing dalam usul pembubaran partai politik. Kedua, relevansi pemberian legal standing bagi perseorangan atau kelompok masyarakat dalam usul pembubaran partai politik. Ketiga, upaya yang dapat dilakukan untuk memberikan legal standing bagi perseorangan atau kelompok masyarakat dalam usul pembubaran partai politik. Metode penelitian yang digunakan yaitu metode yuridis normatif dengan pendekatan perundang-undangan. Hasil penelitian menyimpulkan: pertama, urgensi pemberian legal standing bagi perseorangan atau kelompok masyarakat dalam usul pembubaran partai politik dalam rangka menerjemahkan pelaksanaan kedaulatan rakyat dan prinsip negara hukum. Kedua, dengan diberikannya legal standing kepada perseorangan atau kelompok masyarakat maka pengawasan warganegara terhadap partai politik akan semakin efektif. Ketiga, upaya yang dapat dilakukan untuk memberikan legal standing bagi perseorangan atau kelompok masyarakat dalam usul pembubaran partai politik dengan merevisi UU Mahkamah Konstitusi.
\end{abstract}

Kata kunci: Perseorangan atau kelompok masyarakat, legal standing, pembubaran, partai politik 


\section{Pendahuluan}

Partai politik dan fenomena korupsi di Indonesia dapat diibaratkan dua sisi mata uang, keduanya memiliki hubungan yang cukup erat. Setidaknya, hal itu tercermin dari hasil survei Barometer Korupsi Global Transparansi Indonesia. Selama empat tahun, yakni tahun 2003, 2004, 2007, dan 2008, survei tersebut menempatkan partai politik sebagai lembaga terkorup dalam persepsi publik di Indonesia. ${ }^{1}$ Selain itu, data Transparency International (TI) menunjukkan, pada survei tahun 2003, partai politik tercatat sebagai lembaga terkorup setelah lembaga peradilan. Setahun berikutnya, 2004, partai politik dan parlemen menempati posisi pertama. ${ }^{2}$ Data terbaru yang dirilis Lembaga Survei Nasional (LSN) pada 24 Maret 2013, menunjukkan 70,4 persen dari masyarakat menilai Partai Demokrat sebagai terkorup disusul Partai Golkar 5,7\%, PKS, 4,4\%, PDI Perjuangan 1,7\% di tempat kedua, ketiga dan ke empat. ${ }^{3}$ Korupsi yang dilakukan oleh kader partai politik kini sudah pada taraf yang kronis, karena bukan hanya melibatkan anggota dan pengurus partai politik, tetapi hingga melibatkan ketua umum partai politik.

Data dan fakta di atas menunjukkan bahwa terdapat partai politik yang tidak berjalan on the track. Dalam tataran ideal partai politik mempunyai kewajiban mengamalkan Pancasila, melaksanakan Undang-Undang Dasar Negara Republik Indonesia Tahun 1945 dan peraturan perundang-undangan di bawahnya sebagaimana yang termuat di dalam ketentuan Pasal 40 ayat (2) huruf a Undang-Undang Nomor 2 Tahun 2008 jo Undang-Undang Nomor 2 Tahun 2011 tentang Partai Politik (UU Parpol). Apabila partai politik tidak menjalankan kewajiban-kewajiban konstitusionalnya tersebut, maka seharusnya diberikan sanksi, mulai dari sanksi yang paling ringan hingga sanksi yang paling berat, yaitu pembekuan dan pembubaran partai politik.

Pemberian sanksi merupakan bentuk tanggung jawab negara dalam mengawasi partai politik, sebagai upaya menjaga eksistensi partai politik agar berjalan sesuai koridor yang telah diatur dalam berbagai peraturan perundang-undangan. Instrumen sanksi merupakan upaya preventif dan represif dalam rangka pengawasan partai politik. Hal ini sangat penting karena tanpa adanya sanksi, kemungkinan partai politik keluar dari jalur yang telah diatur dalam peraturan

${ }^{1}$ http://www.antikorupsi.org/id/content/parpol-tak-lepas-dari-jerat-korupsi, diakses tanggal 1 Juni 2013.

${ }^{2}$ Putusan Mahkamah Konstitusi Nomor 53/PUU-IX/2011

${ }^{3}$ http://www.beritaonline.web.id/2013/03/partai-politik-paling-korup-menurut-lembaga-survei.html, diakses tanggal 1 Juni 2013. 
perundang-undangan sangat besar, yang dapat berdampak pada hilangnya kepercayaan masyarakat terhadap partai politik itu sendiri. Apabila hal ini terjadi, tentunya akan menghambat partai politik dalam melaksanakan fungsi komunikasi politik, sosialisasi politik, rekrutmen politik dan sarana pengatur konflik. ${ }^{4}$

Sebagai contoh, partai politik yang melakukan tindak pidana korupsi sudah seharusnya diberikan sanksi, karena jelas melanggar peraturan perundang undangan, yaitu Undang-Undang Nomor 31 Tahun 1999 jo Undang-Undang Nomor 20 Tahun 2001 tentang Tindak Pidana Korupsi ( UU Tipikor). Pasal 40 ayat (2) huruf a UU Parpol menyatakan bahwa partai politik dilarang melakukan kegiatan yang bertentangan dengan Undang-Undang Dasar Negara Republik Indonesia Tahun 1945 dan peraturan perundang-undangan; dan huruf $b$ menyatakan bahwa partai politik dilarang melakukan kegiatan yang membahayakan keutuhan dan keselamatan Negara Kesatuan Republik Indonesia. Berdasarkan ketentuan ini jelas partai politik yang melakukan korupsi dapat dibekukan dan bahkan dibubarkan sebagaimana yang termuat di dalam Pasal 48 ayat (2) dan (3) UU Parpol.

Akan tetapi, permasalahan yang kemudian muncul adalah berkaitan dengan pemegang legal standing untuk pengusulan pembubaran partai politik hanya 'dimonopoli' oleh pemerintah. Hal itu terlihat dalam Undang-Undang Nomor 24 Tahun 2003 jo Undang-Undang Nomor 8 Tahun 2011 tentang Mahkamah Konstitusi dan Putusan Mahkamah Konstitusi Nomor 53/PUU-IX/2011, yang menegaskan bahwa satu-satunya pihak yang dapat mengusulkan pembubaran partai politik hanyalah pemerintah. Sementara, realitas saat ini belum pernah ada inisiatif dari pemerintah untuk mengusulkan pembubaran partainya sendiri walaupun terindikasi korupsi. Pemberian peran tunggal kepada pemerintah untuk mengusulkan pembubaran partai politik jelas menutup pihak lain, seperti perseorangan atau kelompok masyarakat, untuk dapat mengusulkan pembubaran partai politik. Implikasinya, akan tumpul peran warga negara dalam pengawasan partai politik, padahal dalam negara yang demokratis peran warga negara sebagai pemegang kedaulatan tertinggi sangat strategis, apalagi dalam hal pengawasan partai politik yang notabene adalah penyuplai wakil-wakil rakyat di pemerintahan.

Realitas saat ini, peran warga negara dalam melakukan pengawasan terhadap partai politik belum sepenuhnya maksimal. Pengawasan partai politik saat ini oleh

${ }^{4}$ Miriam Budiardjo, Dasar-Dasar Ilmu Politik, PT Grafika Pustaka Utama, Jakarta, 2008, hlm. 405-409. 
warga negara dilakukan melalui mekanisme pemilihan umum, yang mana melalui mekanisme itu warga negara dapat memberikan reward and punishment terhadap kinerja dan aktivitas partai politik. Namun mekanisme pengawasan melalui pemilu sebenarnya terlalu lama dan tidak efektif. Padahal kebutuhan pengawasan itu tidak hanya sekedar ketika pemilu berlangsung, namun juga pasca pemilu dilaksanakan. Pengawasan pasca pemilu penting dilakukan untuk menjaga eksistensi partai politik agar selalu sesuai koridor peraturan perundang-undangan. Hal ini penting dilakukan karena membiarkan partai politik dengan kekuasaan yang besar tanpa ada pengawasan adalah sama dengan membiarkan adanya penyalahgunaan kekuasaan. Potensi penyelewengan atau bahkan penyalahgunaan kekuasaan sangat mungkin terjadi manakala kekuasaan tidak diawasi oleh masyarakat. Bahkan Lord Acton sudah pernah memberikan sinyalemen, bahwa kekuasaan cenderung disalahgunakan, tetapi kekuasaan yang mutlak pasti disalahgunakan (power tends to corrupt, but absolute power corrupts absolutely). ${ }^{5}$

Oleh karena itu, sangat penting adanya upaya merevitalisasi peran warga negara dalam hal ini perseorangan atau kelompok masyarakat untuk lebih efektif melakukan pengawasan terhadap partai politik. Berdasarkan hal tersebut, peneliti menggagas upaya "Pemberian Legal Standing kepada Perseorangan atau Kelompok Masyarakat dalam Usul Pembubaran Partai Politik".

\section{Rumusan Masalah}

Berdasarkan latar belakang tersebut, permasalahan yang menjadi fokus penelitian ini sebagai berikut. Pertama, mengapa perseorangan atau kelompok masyarakat perlu diberikan legal standing dalam usul pembubaran partai politik? Kedua, apa relevansi pemberian legal standing bagi perseorangan atau kelompok masyarakat dalam usul pembubaran partai politik dengan upaya revitalisasi peran warga negara dalam pengawasan partai politik? Ketiga, upaya apa yang dapat dilakukan untuk memberikan legal standing bagi perseorangan atau kelompok masyarakat dalam usul pembubaran partai politik?

\footnotetext{
${ }^{5}$ S.F Marbun, Peradilan Administrasi Negara dan Upaya Administratif di Indonesia, FH UII Press, Yogyakarta, 2011, hlm.7.
} 


\section{Tujuan Penelitian}

Adapun penelitian ini bertujuan untuk mengetahui: pertama, urgensi perseorangan atau kelompok masyarakat diberikan legal standing dalam usul pembubaran partai politik; kedua, relevansi pemberian legal standing bagi perseorangan atau kelompok masyarakat dalam usul pembubaran partai politik dengan upaya revitalisasi peran warga negara dalam pengawasan partai politik; ketiga, upaya yang dapat dilakukan untuk memberikan legal standing bagi perseorangan atau kelompok masyarakat dalam usul pembubaran partai politik.

\section{Metode Penelitian}

Jenis penelitian ini adalah penelitian hukum normatif, karena peneliti melakukan penelitian dengan studi literatur dan peraturan perundang-undangan yang berhubungan dengan objek penelitian guna mencari jawaban atas masalah yang hendak diteliti. Sumber data yang digunakan dalam penelitian ini adalah bahanbahan hukum yang terdiri dari bahan hukum primer, bahan hukum sekunder dan bahan hukum tersier. Bahan hukum primer, merupakan sumber hukum yang mengikat yang terdiri dari peraturan perundang-undangan. Bahan hukum sekunder, diartikan sebagai sumber hukum yang tidak mengikat tetapi menjelaskan bahan hukum primer yang merupakan hasil olahan pendapat atau pikiran para pakar atau ahli yang mempelajari bidang tertentu, berupa buku-buku, makalah-makalah, dan jurnal ilmiah yang berhubungan dengan obyek penelitian. Bahan hukum tersier, yaitu sumber yang memberi penjelasan terhadap bahan hukum primer dan bahan hukum sekunder berupa kamus hukum. Penelitian ini menggunakan teknik pengumpulan bahan hukum melalui metode penelitian library research yang terdiri dari buku-buku, jurnal ilmiah, media massa dan internet serta referensi lain yang relevan. Penelitian ini mengunakan teknik analisis bahan hukum analisis isi (content analysis). Analisis ini dilakukan dengan mengolah bahan-bahan hukum yang telah dikumpulkan secara sistematis untuk menghasilkan kesimpulan yang dapat menjawab rumusan masalah penelitian. 


\section{Hasil Penelitian dan Pembahasan}

\section{Teori Kedaulatan Rakyat dan Demokrasi}

Dalam berbagai literatur politik, hukum, dan teori kenegaraan pada zaman sekarang, terminologi kedaulatan (souvereignty) pada umumnya diakui sebagai konsep yang dipinjam dari bahasa latin, soverain dan superanus, yang kemudian menjadi souvereign dan souvereignty dalam bahasa Inggris yang berarti penguasa dan kekuasaan tertinggi. ${ }^{6}$ Sederhananya, konsep kedaulatan dapat dipahami sebagai konsep kekuasaan tertinggi. Seperti dikemukakan oleh Moh. Kusnardi dan Harmaily Ibrahim, dalam paham kedaulatan rakyat (democracy), rakyatlah yang dianggap sebagai pemilik dan pemegang kekuasaan tertinggi dalam suatu negara. ${ }^{7}$

Sehubungan dengan subjek kedaulatan, dalam sejarah pemikiran hukum dan politik, dikenal adanya lima teori atau ajaran tentang kedaulatan sebagai ide mengenai kekuasaan tertinggi. Kelimanya adalah (i) Teori Kedaulatan Tuhan, (ii) Teori Kedaulatan Raja, (iii) Teori Kedaulatan Negara, (iv) Teori Kedaulatan Rakyat, dan (v) Teori Kedaulatan Hukum. Kelima ajaran tersebut berkembang dalam teori dan praktik dalam sejarah pemikiran mengenai hukum dan negara. ${ }^{8}$ Saat ini kebanyakan doktrin kedaulatan rakyat digunakan sebagai dasar konsep negara demokrasi di zaman modern.

Pada zaman modern ini, hampir semua negara mengklaim menjadi penganut paham demokrasi. ${ }^{9}$ Memang harus diakui sampai sekarang istilah demokrasi itu sudah menjadi bahasa umum yang menunjuk pada pengertian sistem politik yang ideal di mana-mana. Padahal dulunya, pada zaman Yunani Kuno dari mana istilah demokrasi itu berasal, istilah demokrasi itu mempunyai konotasi yang sangat buruk. Demokrasi ("demos" + "cratos" atau "demos"+"kratien" dibayangkan orang sebagai pemerintah oleh semua orang yang merupakan kebalikan dari konsep pemerintahan oleh satu orang (autocracy). ${ }^{10}$ Demokrasi menurut asal kata berarti "rakyat berkuasa" atau "government or rule by the people". Dalam bahasa Yunani demos berarti rakyat, kratos/kratein berarti kekuasaan/berkuasa. ${ }^{11}$ Artinya kekuasaan itu pada pokoknya

\footnotetext{
${ }^{6}$ Jimly Asshiddiqie, Konstitusi dan Konstitusionalisme Indonesia, Cet-2, Sinar Grafika Offset, Jakarta, 2011, hlm.98. ${ }^{7}$ Jimly Asshiddiqie, Pengantar Ilmu Hukum Tata Negara, Cet-3, Rajawali Press, Jakarta, 2011, hlm. 413-414.

${ }^{8}$ Jimly Asshiddiqie, Konstitusi ..., Op. Cit., hlm. 114.

${ }^{9}$ Ibid., hlm. 116.

${ }^{10}$ Ibid.

${ }^{11}$ Ni’matul Huda, Hukum Tata Negara Indonesia, PT Raja Grafindo Persada, Jakarta, 2006, hlm. 241.
} 
diakui berasal dari rakyat sehingga rakyatlah yang sebenarnya menentukan dan memberi arah serta yang sesungguhnya menyelenggarakan kehidupan kenegaraan. Keseluruhan sistem penyelenggaraan negara itu juga pada dasarnya diperuntukkan bagi seluruh rakyat itu sendiri. Bahkan, negara yang baik diidealkan juga agar diselenggarakan bersama-sama dengan rakyat dalam arti dengan melibatkan seluruh masyarakat dalam arti seluas-luasnya.

Penyelenggaraan kedaulatan rakyat tersebut haruslah dipahami karena rakyat memegang kekuasaan tertinggi. Dalam sistem ini, kekuasaan tertinggi dalam suatu negara dianggap berada di tangan rakyat. Kekuasaan itu pada hakikatnya berasal dari rakyat, dikelola oleh rakyat, dan untuk kepentingan seluruh rakyat itu sendiri. Jargon Abraham Lincoln yang kemudian dikembangkan sehubungan dengan ini adalah "kekuasaan itu dari rakyat, oleh rakyat, dan untuk rakyat" ${ }^{12}$ Praktis, bahwa rakyat lebih dimuliakan melalui sistem ini.

Pada hakikatnya, dalam ide kedaulatan rakyat, tetap harus terus dijamin bahwa rakyatlah yang sesungguhnya pemilik kedaulatan dalam negara dengan segala kewenangannya untuk menjalankan seluruh fungsi kekuasaan negara, baik di bidang legislatif, eksekutif, maupun yudikatif. Rakyatlah yang berwenang merencanakan, mengatur, melaksanakan dan melakukan pengawasan serta penilaian terhadap pelaksanaan fungsi-fungsi kekuasaan itu. ${ }^{13}$ Lebih jauh lagi, segala manfaat dari pelaksanaan fungsi-fungsi kekuasaan ini adalah untuk sebesar-besar kemakmuran dan kesejahteraan rakyat, sehingga kedaulatan rakyat yang total adalah kedaulatan rakyat yang sesungguhnya.

Menurut Immanuel Kant, berkaitan dengan teori kedaulatan rakyat, tujuan negara adalah untuk menegakkan hukum dan menjamin kebebasan daripada warga negaranya. Dalam pengertian bahwa kebebasan di sini adalah kebebasan dalam batas-batas perundang-undangan, sedangkan undang-undang di sini yang berhak membuatnya adalah rakyat itu sendiri. Maka kalau begitu, undang-undang adalah merupakan penjelmaan daripada kemauan atau kehendak rakyat. Rakyatlah yang mewakili kekuasaan tertinggi, atau kedaulatan. ${ }^{14}$

Berdasarkan penjelasan di atas, terdapat korelasi yang sangat dekat antara konsepsi kedaulatan rakyat dengan konsepsi demokrasi. Bagir Manan menyatakan,

\footnotetext{
${ }^{12}$ Jimly Asshiddiqie, Konstitusi..., Op. Cit., hlm.117.

${ }^{13}$ Ibid., hlm.118.

${ }^{14}$ Soehino, Ilmu Negara. Yogyakarta, Liberty, Yogyakarta, 2004, hlm. 161.
} 
negara yang demokratis adalah negara yang menempatkan kekuasaan tertinggi pada rakyat. ${ }^{15}$ Pernyataan ini jelas mengindikasikan ada keterkaitan yang sangat erat antara demokrasi dan kedaulatan rakyat. Kedaulatan rakyat diposisikan sebagai syarat bagi suatu negara yang hendak menganut sistem demokrasi.

Demokrasi yang sedang dianut bangsa ini adalah demokrasi perwakilan. Kedaulatan rakyat dengan sistem perwakilan atau demokrasi biasa juga disebut sistem demokrasi perwakilan (representative democracy). ${ }^{16}$ Berdasarkan demokrasi perwakilan, partai politiklah yang didesain memainkan peran dalam pengambilan kebijakankebijakan publik, termasuk rekrutmen kepempimpinan. ${ }^{17}$ Praktiknya, yang menjalankan kedaulatan rakyat itu adalah wakil-wakil rakyat yang duduk di lembaga perwakilan rakyat yang disebut parlemen. Para wakil rakyat itu bertindak atas nama rakyat, dan wakil-wakil rakyat itulah yang menentukan corak dan cara bekerjanya pemerintahan. Agar wakil rakyat benar-benar dapat bertindak atas nama rakyat, wakilwakil rakyat itu harus ditentukan sendiri oleh rakyat, yaitu melalui pemilihan umum (general election). ${ }^{18}$

Di antara sekian banyak aliran pemikiran yang dinamakan demokrasi, ada dua kelompok aliran yang paling penting, yaitu demokrasi konstitusional dan satu kelompok aliran yang menamakan dirinya demokrasi, tetapi yang pada hakikatnya mendasarkan dirinya atas komunisme. Perbedaan fundamental di antara kedua aliran itu ialah bahwa demokrasi konstitusional mencita-citakan sebuah pemerintahan yang terbatas kekuasaannya, yaitu negara hukum (rechstaat) yang tunduk pada rule of law. Sebaliknya, demokrasi yang mendasarkan dirinya atas komunisme, mencita-citakan pemerintah yang tidak boleh dibatasi kekuasaannya (machsstaat) dan yang bersifat totaliter. ${ }^{19}$

Seiring dengan itu Indonesiajuga menganut kedaulatan rakyat (democratie). Pemilik kekuasaan tertinggi yang sesungguhnya dalam negara Indonesia adalah rakyat. Kekuasaan itu harus disadari berasal dari rakyat, oleh rakyat dan untuk rakyat. Bahkan kekuasaan hendaklah diselenggarakan bersama-sama dengan rakyat. ${ }^{20} \mathrm{Hal}$ ini

\footnotetext{
${ }^{15}$ Bagir Manan, "Kedaulatan Rakyat, Hak Asasi Manusia dan Negara Hukum”, dalam Jurnal Konstitusi PSHKFH Universitas Islam Indonesia., Vol. IV No. 2, November 2011, hlm. 63.

${ }^{16}$ Soehino, Ilmu ..., Op cit., hlm. 414

${ }^{17}$ Joko J. Prihatmoko, Mendemokratiskan PEMILU dari Sistem Sampai Elemen Teknis, Pustaka Pelajar. Yogyakarta, 2008, hlm 285.

${ }^{18}$ Soehino, Imu ..., Op. Cit.

${ }^{19}$ Ni'matul Huda, Hukum Tata..., Op.Cit., hlm. 243.

${ }^{20}$ Jimly Asshiddiqie, Konstitusi..., Op. Cit., hlm. 58.
} 
ditegaskan dalam Pasal 1 ayat (2) UUD 1945 bahwa kedaulatan berada di tangan rakyat dan dilaksanakan menurut UUD. Dalam menyalurkan hak kedaulatannya, warga negara dapat melakukan berbagai cara, antara lain melalui hak berserikat dan berkumpul, seperti yang tercantum dalam Pasal 28 (kemerdekaan berserikat dan berkumpul, mengeluarkan pikiran dengan lisan dan tulisan sebagaimana ditetapkan dengan UU, Pasal 28 C ayat (2) (setiap orang berhak untuk memajukan dirinya dalam memperjuangkan haknya secara kolektif untuk membangun masyarakat, bangsa, dan negaranya), dan Pasal 28 D ayat (3) (setiap warga negara berhak memperoleh kesempatan yang sama dalam pemerintahan).

Sebagaimana ditegaskan pada Pasal 1 ayat (2) UUD 1945, konsep kedaulatan rakyat yang sekarang dianut oleh bangsa Indonesia bukanlah kedaulatan rakyat dalam arti yang sebebas-bebasnya. Pelaksanaan kedaulatan rakyat dibatasi dan harus tunduk pada aturan hukum. Bagaimana pun kedaulatan rakyat (democratie) tetaplah mempunyai kelemahan-kelemahan, salah satunya bahwa jika tidak terkontrol dengan baik maka akan menimbulkan tindakan yang anarkis. Oleh karena itu, dalam Pasal 1 ayat (2) UUD 1945 ditegaskan, bahwa kedaulatan rakyat dilaksanakan menurut Undang-Undang Dasar, menunjukkan bahwa pelaksaanaan kedaulatan rakyat disalurkan dan diselenggarakan menurut prosedur konstitusional yang ditetapkan dalam hukum dan konstitusi (constitutional democracy).

Pasal 1 ayat (3) Undang-Undang Dasar 1945 menegaskan, bahwa Indonesia adalah negara hukum, konsekuensinya adalah bahwa segala hal dalam kehidupan berbangsa dan bernegara, termasuk pelaksanaan kedaulatan rakyat haruslah dibarengi dengan aturan hukum. Antara kedaulatan rakyat dan prinsip negara hukum harus dilaksanakan secara beriringan. Untuk itulah, Undang-Undang Dasar Republik Indonesia hendaklah menganut pengertian bahwa negara Republik Indonesia adalah negara hukum yang demokratis (democratische rechststaat) dan sekaligus adalah negara demokrasi yang berdasar atas hukum (constitutional democracy) yang tidak terpisahkan satu sama lain. ${ }^{21}$

\section{Legal Standing bagi Perseorangan atau Kelompok Masyarakat dalam Usul Pembubaran Partai Politik}

Ketentuan Pasal 1 ayat (2) UUD 1945 menyatakan bahwa “Kedaulatan berada di tangan rakyat dan dilaksanakan menurut Undang-Undang Dasar". Hal ini

${ }^{21}$ Ibid., hlm. 58 
menunjukkan bahwa rakyat diposisikan sebagai pemilik kekuasaan tertinggi di Indonesia. Pemilik kekuasaan tertinggi yang sesungguhnya di negara Indonesia adalah rakyat. Kekuasaan itu harus disadari berasal dari rakyat, oleh rakyat dan untuk rakyat. Bahkan kekuasaan hendaklah diselenggarakan bersama-sama dengan rakyat. $^{22}$

Penyelenggaraan kedaulatan rakyat tersebut haruslah dipahami karena rakyat memegang kekuasaan tertinggi. Dalam sistem ini, kekuasaan tertinggi dalam suatu negara dianggap berada di tangan rakyat. Kekuasaan itu pada hakikatnya berasal dari rakyat, dikelola oleh rakyat, dan untuk kepentingan seluruh rakyat itu sendiri. Jargon yang kemudian dikembangkan sehubungan dengan ini adalah "kekuasaan itu dari rakyat, oleh rakyat, dan untuk rakyat". ${ }^{23}$ Praktis, bahwa rakyat lebih dimuliakan melalui sistem ini.

Pada hakikatnya, dalam ide kedaulatan rakyat itu, tetap harus terus dijamin bahwa rakyatlah yang sesungguhnya pemilik negara dengan segala kewenangannya untuk menjalankan seluruh fungsi kekuasaan negara, baik di bidang legislatif, eksekutif, maupun yudikatif. Rakyatlah yang berwenang merencanakan, mengatur, melaksanakan dan melakukan pengawasan serta penilaian terhadap pelaksanaan fungsi-fungsi kekuasaan itu. ${ }^{24}$ Lebih jauh lagi, segala manfaat dari pelaksanaan fungsi-fungsi kekuasaan ini adalah untuk sebesar-besar kemakmuran dan kesejahteraan rakyat sehingga kedaulatan rakyat yang total adalah kedaulatan rakyat yang sesungguhnya.

Warga negara dapat melakukan berbagai cara untuk menyalurkan hak kedaulatannya antara lain melalui hak berserikat dan berkumpul, seperti yang tercantum dalam Pasal 28 UUD 1945 (kemerdekaan berserikat dan berkumpul, mengeluarkan pikiran dengan lisan dan tulisan sebagaimana ditetapkan dengan undang-undang). Pasal inilah yang juga menjadi alasan warga negara membentuk partai poltik yang kemudian diatur lebih lanjut dalam Undang-undang Nomor 2 Tahun 2008 jo Undang-Undang Nomor 2 Tahun 2011 tentang Partai Politik.

Secara umum dapat dikatakan bahwa partai politik adalah suatu kelompok terorganisir yang anggota-anggotanya mempunyai orientasi, nilai-nilai, dan citacita yang sama. Tujuan kelompok ini adalah untuk memperoleh kekuasaan politik

\footnotetext{
${ }^{22}$ Jimly Asshiddiqie, Konstitusi..., Op. Cit., hlm. 58

${ }^{23}$ Ibid., hlm.117.

${ }^{24}$ Ibid., hlm.118.
} 
dan merebut kedudukan politik biasanya dengan cara konstitusional untuk melaksanakan programnya. ${ }^{25}$ Fungsi partai politik antara lain sebagai sarana komunikasi politik, sosialiasi politik, rekrutmen politik, dan sarana pengatur konflik. ${ }^{26}$ Dengan demikian, partai politik mempunyai posisi (status) dan peranan (role) yang sangat penting dalam setiap sistem demokrasi.

Partai politik merupakan pilar yang sangat penting untuk diperkuat derajat pelembagaannya (the degree of institutionalization) dalam setiap sitem politik yang demokratis. ${ }^{27}$ Untuk itu dapat dikatakan bahwa sebenarnya esensi dari partai politik adalah sebagai salah satu sarana untuk mewujudkan sistem politik yang demokratis. Partai politik adalah salah satu sarana untuk mewujudkan sistem politik yang demokratis. Mengapa? Karena dalam sistem politik yang demokratis salah satu cirinya adalah jaminan terhadap hak asasi manusia.

Partai politik itu sendiri berdiri berdasarkan Pasal 28 Undang Undang Dasar 1945. Affan Gaffar menyatakan bahwa, dalam suatu negara yang demokratis, setiap warga masyarakat dapat menikmati hak-hak dasar mereka secara bebas, termasuk di dalamnya adalah hak untuk menyatakan pendapat (freedom of expression), hak untuk berkumpul dan berserikat (freedom of assembly), dan hak untuk menikmati pers yang bebas (freedom of the press). ${ }^{28}$ Selain itu dalam sistem politik yang demokratis itu masyarakat diberikan kewenangan atau hak untuk menentukan siapa yang akan menjadi pemimpin mereka. Hal ini menjadi konsekuensi yang logis dari sebuah sistem yang bernama kedaulatan rakyat

Berbicara partai politik pasti tidak akan terlepas dari pembahasan demokrasi yang sedang dianut bangsa ini yaitu demokrasi perwakilan. Kedaulatan rakyat dengan sistem perwakilan atau demokrasi biasa juga disebut sistem demokrasi perwakilan (representative democracy). ${ }^{29}$ Berdasarkan demokrasi perwakilan, partai politiklah yang didesain memainkan peran dalam pengambilan kebijakan-kebijakan publik, termasuk rekrutmen kepempimpinan. ${ }^{30}$ Praktiknya, yang menjalankan kedaulatan rakyat itu adalah wakil-wakil rakyat yang duduk di lembaga perwakilan rakyat yang disebut parlemen. Para wakil rakyat itu bertindak atas nama rakyat,

${ }^{25}$ Miriam Budiardjo, Dasar-dasar..., Op. Cit., hlm. 404.

${ }^{26} \mathrm{Ibid}$.

${ }^{27}$ Jimly Asshiddiqie, Pengantar..., Op. Cit., hlm. 401.

${ }^{28}$ Affan Gaffar, Politik. Indonesia Transisi Menuju Demokrasi, Pustaka Pelajar, Yogyakarta, 1999, hlm. 9.

${ }^{29}$ Jimly Asshiddiqie, Pengantar..., hlm. 414.

${ }^{30}$ Joko J.Prihatmoko, Mendemokratiskan PEMILU dari Sistem Sampai Elemen Teknis, Pustaka Pelajar, Yogyakarta, 2008, hlm. 285. 
dan wakil-wakil rakyat itulah yang menentukan corak dan cara bekerjanya pemerintahan. Agar wakil rakyat benar-benar dapat bertindak atas nama rakyat, wakil-wakil rakyat itu harus ditentukan sendiri oleh rakyat, yaitu melalui pemilihan umum (general election). ${ }^{31}$

Pemilu itu mensyaratkan adanya partai politik. Antara pemilu dan partai politik mempunyai hubungan yang sangat erat yang pada akhirnya akan bermuara bahwa partai politik itu sendiri adalah milik rakyat. Tanpa adanya rakyat maka tidak akan ada demokrasi, pemilu ataupun partai politik sehingga pusat kekuasaan berdasarkan prinsip kedaulatan rakyat adalah rakyat. Karena partai politik berdiri atas kebutuhan rakyat, maka rakyat juga harus diberikan hak untuk mengawasi aktivitas partai politik. Apakah sesuai amanat atau tidak maka rakyat harus diberikan hak untuk usul dalam pembubaran partai politik. Jika eksistensi partai politik membahayakan negara maka rakyat bisa usul untuk membubarkan partai politik sebagaimana rakyat punya hak untuk mendirikan partai politik.

Undang-undang partai politik pada dasarnya mengatur larangan-larangan terhadap tindakan yang tidak semestinya dilakukan oleh partai politik yang apabila dilanggar maka partai politik tersebut akan mendapatkan sanksi. Hal ini tepat, walaupun hak asasi manusia diakui sebagai hak yang melekat pada setiap orang karena kemanusiaannya namun terdapat pembatasan-pembatasan terhadap hak tersebut.

Aturan mengenai larangan itu sebenarnya dimaksudkan sebagai bentuk pembatasan hak. Aturan tersebut tertuang dalam Pasal 40 UU Parpol ${ }^{32}$ : (1) Partai Politik dilarang menggunakan nama, lambang, atau tanda gambar yang samadengan: (a) bendera atau lambang negara Republik Indonesia; (b) lambang lembaga negara atau lambang Pemerintah; (c) nama, bendera, lambang negara lain atau lembaga/ badan internasional; (d) nama, bendera, simbol organisasi gerakan separatis atau organisasiterlarang; (e) nama atau gambar seseorang; atau (f) yang mempunyai persamaan pada pokoknya atau keseluruhannya dengan nama, lambang, atau tanda gambar Partai Politik lain. (2) Partai Politik dilarang: (a) melakukan kegiatan yang bertentangan dengan Undang-Undang Dasar Negara Republik Indonesia Tahun 1945 dan peraturan perundang-undangan; atau (b) melakukan kegiatan yang membahayakan keutuhan dan keselamatan Negara Kesatuan Republik Indonesia.

\footnotetext{
${ }^{31}$ Jimly Asshiddiqie, Pengantar..., hlm. 414

${ }^{32}$ Pasal 40 Undang-Undang Nomor 2 Tahun 2008 jo Undang-Undang Nomor 2 Tahun 2011.
} 
(3) Partai Politik dilarang: (a) menerima dari atau memberikan kepada pihak asing sumbangan dalam bentuk apapun yang bertentangan dengan peraturan perundangundangan; (b) menerima sumbangan berupa uang, barang, ataupun jasa dari pihak mana pun tanpa mencantumkan identitas yang jelas; (c) menerima sumbangan dari perseorangan dan/atau perusahaan/badan usaha melebihi batas yang ditetapkan dalam peraturan perundang-undangan; (d) meminta atau menerima dana dari badan usaha milik negara, badan usaha milik daerah, dan badan usaha milik desa atau dengan sebutan lainnya; atau (e) menggunakan fraksi di Majelis Permusyawaratan Rakyat, Dewan Perwakilan Rakyat, Dewan Perwakilan Rakyat Daerah provinsi, dan Dewan Perwakilan Rakyat Daerah kabupaten/kota sebagai sumber pendanaan Partai Politik. (4) Partai Politik dilarang mendirikan badan usaha dan/ atau memiliki saham suatu badan usaha. (5) Partai Politik dilarang menganut dan mengembangkan serta menyebarkan ajaran atau paham komunisme/Marxisme-Leninisme.

Mengenai sanksi, undang-undang Partai Politik mengatur beberapa jenis sanksi diantaranya sanksi administratif, sanksi pembekuan, dan sanksi pembubaran partai politik sebagaimana diatur dalam Pasal 48. Adanya sanksi tersebut adalah dalam rangka pembatasan hak. Adanya pembatasan harus benar-benar sesuai dengan tujuan pembatasan itu sendiri, diantaranya adalah untuk melindungi hak dan kebebasan lain. Oleh karena itu, pembatasan harus ditafsirkan secara ketat yang meliputi bahwa pembatasan harus diatur dalam aturan hukum, harus dilakukan semata-mata untuk mencapai tujuan dalam masyarakat demokratis dan harus memang benar-benar dibutuhkan dan bersifat proporsional sesuai dengan kebutuhan sosial. ${ }^{33}$

Pembatasan hak yang harus diatur dalam norma hukum merupakan manifestasi prinsip negara hukum. Prinsip negara hukum mensyaratkan adanya perlindungan terhadap hak asasi manusia. Pembatasan sebagaimana disebutkan diatas adalah bagian dari upaya melindungi hak asasi antar warga negara yang satu dengan yang lain. Selain itu prinsip negara hukum juga mensyaratkan bahwa seluruh aktivitas penyelenggara negara juga didasarkan atas ketentuan hukum yang berlaku. Dengan demikian pembatasan hak asasi manusia sebagaimana dimaksud diatas juga perlu dimuat dalam aturan perundang-undangan.

Pembubaran partai politik di Indonesia tertuang dalam UU Parpol dan UndangUndang Nomor 24 Tahun 2003 tentang Mahkamah Konstitusi jo Undang-Undang

${ }^{33}$ Muchamad Ali Safa'at, Pembubaran Partai Politik Pengaturan dan Praktik Pembubaran Partai Politik dalam Pergulatan Republik, Rajawali Press, Jakarta, 2011, hlm. 38. 
Nomor 8 Tahun 20011 (UU MK). Pasal 68 ayat (1) Undang-undang Nomor 24 Tahun 2003 tentang Mahkamah Konstitusi dinyatakan dengan jelas bahwa pemohon untuk perkara pembubaran partai politik di Mahkamah Konstitusi adalah Pemerintah, yaitu jelasnya adalah Pemerintah Pusat yang diwakili oleh Menteri Dalam Negeri atau Jaksa Agung. Kewenangan pemerintah untuk menjadi pemohon terkait dengan tanggungjawab pemerintah untuk menjalankan Undang-Undang Dasar dan segala peraturan perundang-undangan yang berlaku, serta mengupayakan tegaknya Undang-Undang Dasar beserta segala peraturan perundang-undangan itu dengan sebaik-baiknya sesuai dengan hukum. ${ }^{34}$ Ketentuan terkait dengan pemohon pembubaran partai politik, dengan demikian praktis hanya memberikan legal standing kepada pemerintah dan tidak ada yang lain.

Oleh karena itu, jika suatu partai politik dinilai oleh Pemerintah telah melanggar Undang-Undang Dasar dan/atau peraturan perundang-undangan yang berlaku, maka adalah tanggung jawab pemerintah untuk mengambil inisiatif guna membubarkan partai politik yang bersangkutan menurut prosedur hukum yang berlaku. ${ }^{35}$ Namun yang menjadi permasalahan, apakah hanya pemerintah saja yang berhak menjadi pemohon dalam perkara pembubaran partai politik?

Mahfud MD mengatakan bahwa wewenang pembubaran partai politik tidak boleh lagi berada di tangan pemerintah karena pada prinsipnya pemerintah dibentuk oleh partai politik ${ }^{36}$. Lebih lanjut Jimly Asshiddiqqie juga menegaskan bahwa dalam sistem yang demokratis, pembatasan, pembubaran, pelarangan terhadap suatu organisasi, termasuk partai politik, hanya dapat dilakukan berdasarkan alasan-alasan yang rasional dan proporsional serta melalui mekanisme due process of law dan berdasarkan putusan pengadilan. Pembubaran partai politik tidak dapat diserahkan kepada pemerintah karena berpotensi terjadi penyalahgunaan kekuasaan. Partai politik yang memenangkan pemilihan umum dapat menggunakan kekuasannya sebagai partai pemerintah (governing party) untuk menjegal saingannya. ${ }^{37}$

Apalagi kenyataan yang sekarang kita hadapi justru partai pemerintah yang bermasalah. Jika partai pemerintah yang bermasalah apakah sudah sesuai jika legal

${ }^{34}$ Jimly Asshiddiqie, Kemerdekaan Berserikat Pembubaran Partai Politik dan Mabkamah Konstitusi, Konstitusi Press, Jakarta, 2005, hlm.138.

${ }^{35}$ Ibid.

${ }^{36}$ Muchamad Ali Safa'at, Pembubaran ..., Op. Cit., hlm. vii.

${ }^{37}$ Ibid., hlm. xi 
standing pemohon pembubaran partai politik hanya diberikan kepada pemerintah? Menjadi hal yang hampir tidak mungkin. Oleh sebab itu, solusi yang paling tepat menghadapi realitas saat ini adalah dengan memberikan legal standing kepada warga negara yang dalam hal ini adalah perseorangan atau kelompok masyarakat untuk menjadi pemohon dalam perkara pembubaran partai politik. Pemberian legal standing ini dilakukan dalam rangka untuk melakukan pengawasan terhadap partai politik.

Sebagai contoh di Slovenia, setiap orang berhak mengajukan inisiatif permohonan pembubaran partai politik sebagaimana tertuang dalam bab VIII Deciding On The Unconstitutionality Of The Acts And Activities Of Political Parties, Article 68 Paragraph 1 The Contitutional Court Act Slovenia menyebutkan: "Anyone may lodge a petition, and the applicants referred to in Article 23 of this Act may submit a request to review the unconstitutionality of the acts and activities of political parties". ${ }^{38}$ Model Slovenia ini sesungguhnya yang paling cocok diterapkan sesuai dengan sosial, politik dan budaya di Indonesia serta kondisi carut marutnya partai politik di Indonesia yang korup dan tidak membela kepentingan rakyat, agar seluruh rakyat Indonesia dapat mengontrol partai politik.

Pemberian legal standing untuk warga negara sebagai pemohon perkara pembubaran partai politik adalah dalam rangka menerjemahkan pelaksanaan kedaulatan rakyat dan prinsip negara hukum. Sebagai pelaksanaan kedaulatan rakyat pemberian legal standing tersebut sangat penting karena pada pada dasarnya partai politik itu berdiri atas kebutuhan rakyat. Jika tujuan dan aktivitas partai politik itu sudah melenceng dan tak sesuai lagi dengan kehendak rakyat bahkan melanggar peraturan perundang-undangan yang berlaku, maka rakyat harus mengevaluasinya. Pemberian legal standing tersebut adalah bagian dari cara mengevaluasi partai politik. Jika eksistensi partai politik membahayakan negara maka seharusnya rakyat diberikan hak untuk mengusulkan pembubaran partai politik sebagaimana dia punya hak untuk mendirikan partai politik.

Di sisi lain, sebagai pelaksanaan prinsip negara hukum, pemberian legal standing sebagaimana dimaksud di atas sangat penting karena salah satu prinsip utama dalam negara hukum adalah adanya jaminan terhadap perlindungan hak asasi manusia. Pembubaran partai politik merupakan bagian dari pembatasan hak asasi dalam

\footnotetext{
${ }^{38}$ http://www.us-rs.si/en/about-the-court/legal-basis/statutes/constitutional-court-act/viii-deciding-on-theunconstitutionality-of-the-ac/ [24 juni 2013]
} 
rangka menjamin hak asasi warga negara lainnya. Namun apabila usul pembubaran partai politik itu hanya diberikan kepada pemerintah, tentu belum menjamin hak asasi seluruh warga negara. Sebagai upaya mewujudkan jaminan hak asasi manusia terhadap seluruh warga negara, maka pemberian legal standing terhadap perseorangan atau kelompok masyarakat tidak dapat ditawar lagi, karena dengan hal inilah Indonesia dapat menguatkan eksistensinya sebagai negara hukum.

\section{Relevansi Pemberian Legal Standing bagi Perseorangan atau Kelompok Masyarakat dalam Usul Pembubaran Partai Politik}

Pengaturan partai politik menjadi salah satu kecenderungan utama negara demokrasi modern mengingat peran partai politik yang semakin penting. ${ }^{39}$ Pengaturan partai politik diperlukan untuk mewujudkan sistem kepartaian yang sesuai dengan tipe demokrasi yang dikembangkan dan sesuai dengan kondisi bangsa Indonesia. Pengaturan tentang partai politik juga dimaksudkan untuk menjamin kebebasan patai politik itu sendiri, serta membatasi campur tangan berlebihan dari pemerintah yang dapat memasung kebebasan dan peran partai politik sebagai salah satu instruksi yang diperlukan untuk menjamin kedaulatan rakyat. ${ }^{40}$ Pengaturan partai politik merupakan bagian dari proses institusionalisasi untuk mengembangkan demokrasi. Salah satu aspek pengaturan partai politik adalah pembubaran partai politik sebagai salah satu bentuk pembatasan hak asasi manusia khususnya berserikat. $^{41}$

Batasan terhadap kebebasan berserikat sebagai hak asasi manusia diperlukan dalam masyarakat demokratis demi keamanan nasional dan keselamatan publik, untuk mencegah kejahatan, untuk melindungi kesehatan dan moral, serta untuk melindungi hak dan kebebasan lain. ${ }^{42}$ Pembatasan yang dibutuhkan dalam masyarakat demokratis merupakan garis apresiasi yang menyeimbangkan antara kepentingan publik dan privat. Pembatasan tersebut harus ditafsirkan secara ketat yang meliputi; bahwa pembatasan harus diatur dalam aturan hukum; harus

\footnotetext{
${ }^{39}$ Miriam Budiardjo, Dasar-Dasar..., Op. Cit., hlm. 405-409.

${ }^{40}$ Salah satu kesimpulan dari survei yang dilakukan Venice Commission di negara-negara Eropa menunjukkan bahwa aktivitas partai politik dijamin oleh prinsip kebebasan berserikat. Bahkan adanya tindakan pembatasan itu sendiri merupakan wujud perhatian terhadap pelaksanaan prinsip kebebasan berserikat. Lihat European Commision for Democracy Through Law (Venice Commission), Guideline on Prohibition. Yang dikutip dari Muchamad Ali Safa'at, Pembubaran..., Op. Cit., hlm. 299.

${ }^{41}$ Ibid.

${ }^{42}$ Hiaire Barnett, Constitutional \& Administrative Law, Fifth Edison, Cavendosh Publishing Limited, LondonSydney-Portland, Oregon, 2004, hlm.589, Ibid., hlm. 23.
} 
dilakukan semata-mata untuk mencapai tujuan dalam masyarakat demokratis; dan harus memang benar-benar dibutuhkan dan bersifat proporsional sesuai dengan kebutuhan sosial. ${ }^{43}$

Menurut Sam Issacharoff, salah satu bentuk pembatasan yang dapat dibenarkan dan dibutuhkan dalam negara demokrasi, adalah pembatasan terhadap kelompok yang mengancam demokrasi, kebebasan, serta masyarakat secara keseluruhan. Negara dapat melarang atau membubarkan suatu organisasi, termasuk partai politik, yang bertentangan dengan tujuan dasar dan tatanan konstitusional. Negara demokrasi tidak hanya memiliki hak, tetapi juga tugas untuk menjamin dan melindungi prinsip-prinsip demokrasi konstitusional. ${ }^{44}$

Hanya saja di dalam realitanya pengaturan dan pembatasan tersebut tidak berjalan sesuai yang diharapkan. Di Indonesia, pengaturan partai politik dalam konteks usul pembubaran partai politik yang bermasalah hanya dapat dilakukan oleh pemerintah, padahal sudah dijelaskan di atas bahwa hal tersebut tentu saja berimplikasi tidak baik, yaitu menumpulkan peran warga negara dalam pengawasan partai politik. Perlu adanya upaya merevitalisasi peran warga negara dalam pengawasan partai politik melalui pemberian legal standing bagi perseorangan atau kelompok masyarakat.

Perlu diketahui bahwasanya demokrasi itu tidak selamanya baik. Demokrasi tetap mempunyai kelemahan-kelemahan, salah satunya jika demokrasi itu tidak terkontrol dengan baik, akan timbullah sebuah tindakan yang anarki. Sehingga demokrasi harus sesuai dengan aturan hukum yang berlaku. Secara substantif demokrasi harus diperkuat, seseorang atau kelompok masyarakat diberikan hak mengusulkan pembubaran partai politik harus dimaknai untuk menjaga eksistensi demokrasi yang berkualitas.

Melalui pemberian legal standing bagi perseorangan atau kelompok masyarakat dalam usul pembubaran partai politik, peran warga negara dalam pengawasan partai politik tidak lagi dapat dikatakan tumpul tetapi sebaliknya peran warga negara dalam pengawasan partai politik dirasa semakin maksimal. Bagaimana tidak, hakhak konstitusional warga negara yang terdapat di dalam ketentuan Pasal 1 ayat (2) Undang-Undang Dasar 1945 bahwa “kedaulatan berada di tangan rakyat dan dilaksanakan menurut Undang-Undang Dasar akan menjadi terpenuhi manakala

\footnotetext{
${ }^{4}$ Janusz Symonides, Human Roghts: Concept and Standards, (Aldordshot-Burlingston USA-Sigapore-Sydney: UNESCO Publishing, 2000), hlm. 91-92. Ibid., hlm. 23-24

${ }^{44}$ Sam Issacharoff, Fragile Democraties, New York University Public Las and Legal Theory Working Paper, Paper 40, Year 2006, hlm. 6 dan 22, Ibid.
} 
perseorangan atau kelompok masyarakat diberikan legal standing dalam usul pembubaran partai politik tersebut.

Hal ini menjadi warning tersendiri bagi partai politik. Jika sewaktu-waktu partai politik tidak menjalankan amanah rakyat, sewaktu-waktu pula rakyat dapat melakukan koreksi yang korektif yaitu melalui usul pembubaran partai politik. Jika rakyat yang dalam hal ini adalah perseorangan atau kelompok masyarakat diberikan kewenangan dalam usul pembubaran partai politik dan kemudian partai politik tersebut dibubarkan oleh Mahkamah Konstitusi, ini sebenarnya adalah sinyal bagi siapapun yang ingin mendirikan partai politik di Indonesia agar tidak mengesampingkan kedaulatan dan kepentingan rakyat. Hal ini juga dapat menimbulkan efek jera kepada partai-partai politik yang berjalan tidak pada koridor yang semestinya sebagaimana yang dijelaskan diatas. Berdasarkan hal di atas, maka pemberian legal standing bagi perseorangan atau kelompok masyarakat sangat relevan dilakukan sebagai upaya merevitalisasi peran warga negara dalam pengawasan partai politik.

\section{Upaya Pemberian Legal Standing bagi Perseorangan atau Kelompok Masyarakat dalam Usul Pembubaran Partai Politik.}

Putusan Mahkamah Konstitusi No.53/PUU-IX/MK-2011 menegaskan bahwa Mahkamah Konstitusi tidak mengabulkan adanya pemberian legal standing kepada perseorangan dalam usul pembubaran partai politik. Pertimbangan hukumnya, Mahkamah Konstitusi menyatakan bahwa Pasal 24C UUD 1945 tidak mengatur mengenaiyang berhak mengajukan perkara pembubaran partai politik ke Mahkamah Konstitusi. Pemerintah sebagai pemohon dalam perkara pembubaran partai politik merupakan pilihan pembentuk Undang-Undang dalam menyusun dan membentuk ketentuan hukum acara Mahkamah Konstitusi dalam Undang-undang Mahkamah Konstitusi, sehingga Pasal 68 ayat (1) Undang-undang Mahkamah Konstitusi tersebut tidak bertentangan dengan ketentuan mengenai kewenangan Mahkamah Konstitusi dalam Pasal 24C UUD 1945. Memang di dalam UUD khususnya Pasal 24C hanya meyebut kewenangan Mahkamah Konstitusi yang salah satu kewenangannya adalah memutus pembubaran partai politik, tidak menjelaskan secara rinci mengenai permohon perkara pembubaran partai politik. Terkait dengan pemohon perkara pembubaran partai politik ini diatur di dalam ketentuan Pasal 68 ayat (1) Undangundang Mahkamah Konstitusi. ${ }^{45}$

\footnotetext{
${ }^{45}$ Putusan Mahkamah Konstitusi No. 53/PUU-IX/2011
} 
Pemohon pada petitum permohonan perkara a quo, memohon kepada Mahkamah Konstitusi untuk memutuskan frasa"Pemerintah" pada Pasal 68 ayat (1) Undang-undang MK bertentangan dengan UUD 1945,kecuali sepanjang dimaknai: "tidak hanya pemerintah yang dapat mengajukanpermohonan pembubaran partai politik ke Mahkamah Konstitusi, tetapi dapat pula perorangan warga negara Indonesia dan badan hukum". Mahkamah Konstitusi menilai bahwa rumusan yang diinginkan oleh para Pemohon tersebut merupakan rumusan konstitusional bersyarat yang menambah norma baru pada Undang-Undang. Menurut Mahkamah, katakata"Pemerintah" pada Pasal 68 telah diartikan secara tegas dalam penjelasannya sebagai "Pemerintah Pusat" dan tidak dapat diartikan atau ditafsirkan dengan menambah "perorangan warga negara Indonesia dan badan hukum" sebagai pemohon pembubaran partai politik, karena hal tersebut menjadi penambahan norma baru. Apabila Mahkamah menghapus atau menyatakan tidak memilki kekuatan hukum terhadap frasa "Pemerintah" pada Pasal 68 ayat (1) Undang-Undang a quo, maka norma pada UU MK mengenai yang dapat menjadi pemohon pada perkara pembubaran partai politik menjadi tidak jelas sehingga akan menimbulkan kekosongan dan ketidakpastian hukum. ${ }^{46}$

Ditambahkan lagi dalam pertimbangan selanjutnya bahwa keinginan para Pemohon agar pihak yang dapat mengajukan permohonan pembubaran partai politik ke Mahkamah Konstitusi ditambah dengan perorangan warga negara dan badan hukum merupakan kewenangan dari pembentuk Undang-Undang untuk mengubahnya (legislative review). Mahkamah tidak berwenang untuk menambah pemohon dalam pembubaran partai politik sesuai dengan keinginan para Pemohon, Mahkamah hanya berwenang menyatakan materi muatan, ayat, pasal, dan/atau bagian dari Undang-Undang bertentangan atau tidak bertentangan dengan UndangUndang Dasar Negara Republik Indonesia Tahun 1945 (vide Pasal 56 ayat (3) Undangundang Mahkamah Konstitusi. ${ }^{47}$

Menilik pertimbangan Mahkamah Konstitusi di atas dapat ditarik kesimpulan bahwa penambahan kata-kata perseorangan warga negara atau badan hukum dapat menjadi pemohon perkara pembubaran partai politik adalah sama saja dengan menambah norma baru. Penambahan norma baru adalah ranah legislatif. Berdasarkan putusan tersebut secara tersirat Mahkamah Konstitusi sebenarnya

\footnotetext{
${ }^{46}$ Ibid.

${ }^{47}$ Ibid.
} 
menyetujui jika perseorangan warganegara atau badan hukum diberikan legal standing sebagai pemohon perkara pembubaran partai politik hanya saja jalannya tidak melalui proses judicial review.

Untuk itu, penulis mengusulkan perlunya revisi Undang-undang Mahkamah Konstitusi khususnya Pasal 68. Pemohon tidak hanya diberikan kepada pemerintah melainkan warganegara dalam hal ini perseorangan atau kelompok masyarakat harus diberikan legal standing sebagai pemohon dalam perkara pembubaran partai politik. Jadi pemohon dalam perkara pembubaran partai politik terdiri dari 2 (dua) unsur yaitu pemerintah dan warganegara yang konkritnya adalah perseorangan atau kelompok masyarakat.

Penulis mengusulkan revisi Pasal 68 ayat (1) sebagai berikut: “Pemohon adalah Pemerintah, Perseorangan atau Kelompok Masyarakat". Sedangkan penjelasan pada pasal 68 ayat (1) ditambahkan redaksi: “Yang dimaksud dengan perseorangan atau kelompok masyarakat adalah Perseorangan atau kelompok masyarakat yang berkewarganegaraan Indonesia". Implikasi dari rumusan di atas adalah pertama, jalur pemohon tidak lagi hanya pemerintah tetapi mengakomodir perseorangan atau kelompok masyarakat yang berkewarganegaraan Indonesia; kedua, mengembalikan kedaulatan ditangan rakyat; ketiga, menjamin pemenuhan hak asasi warganegara sebagai manifestasi prinsip negara hukum; serta yang keempat,dapat merevitaliasi peran warga negara dalam hal ini perseorangan atau kelompok masyarakat dalam melaksanakan pengawasan terhadap partai politik.

Terdapat kekhawatiran bahwa jika perseorangan atau kelompok masyarakat diberikan legal standing dalam usul pembubaran partai politik berpotensi banyaknya permohonan usul pembubaran partai politik yang bisa jadi disalahgunakan oleh oknum-oknum tertentu untuk menjatuhkan lawan politiknya. Untuk mengantisipasi hal tersebut, Penulis juga memberikan satu solusi yaitu bahwa setiap permohonan yang berkaitan dengan pelanggaran yang dilakukan oleh partai politik yang bersifat pidana, perdata, maupun administrasi pemohon wajib melampirkan bukti pelanggaran tersebut berupa putusan pengadilan yang telah berkekuatan hukum tetap (inkracht).

Berdasarkan hal tersebut maka Peneliti mengusulkan agar rumusan Pasal 68 ditambahkan 1 ayat yang berbunyi: "Pemohon wajib melampirkan putusan pengadilan yang berkekuatan hukum tetap (inkracht) berkaitan dengan pelanggaran terhadap peraturan perundang-undangan. 


\section{Penutup}

Berdasarkan analisis dan pembahasan di atas dapat ditarik kesimpulan sebagai berikut. Pertama, urgensi pemberian legal standing bagi perseorangan atau kelompok masyarakat dalam usul pembubaran partai politik adalah dalam rangka menerjemahkan pelaksanaan kedaulatan rakyat dan prinsip negara hukum. Sebagai upaya mewujudkan jaminan hak asasi manusia terhadap seluruh warga negara, maka pemberian legal standing terhadap perseorangan atau kelompok masyarakat tidak dapat ditawar lagi, karena dengan hal inilah Indonesia dapat menguatkan eksistensinya sebagai negara hukum. Kedua, dengan diberikannya legal standing bagi perseorangan atau kelompok masyarakat maka pengawasan warganegara terhadap partai politik akan semakin efektif karena warganegara dapat secara langsung melakukan koreksi yang konstruktif yaitu melalui usul pembubaran partai politik. Hal ini juga menjadi warning bagi partai politik yang tidak menjalankan amanah rakyat serta juga dapat menimbulkan efek jera kepada partai-partai politik yang berjalan tidak pada koridor yang semestinya.

Ketiga, upaya yang dapat dilakukan untuk memberikan legal standing bagi perseorangan atau kelompok masyarakat dalam usul pembubaran partai politik adalah merevisi Pasal 68 Undang-undang Mahkamah Kostitusi beserta penjelasannya dengan mengakomodir perseorangan atau kelompok masyarakat sebagai pemohon perkara usul pembubaran partai politik. Selain itu perlu ditambahkan satu ayat yang mengatur tentang kewajiban para pemohon untuk melampirkan bukti berupa putusan pengadilan yang telah berkekuatan hukum tetap (inkracht) terhadap pelanggaran hukum yang dilakukan oleh partai politik.

Untuk itu peneliti memberikan saran bagi pemerintah dan Dewan Perwakilan Rakyat (DPR) untuk segera merevisi Pasal 68 Undang-Undang Mahkamah Kostitusi beserta penjelasannya dengan mengakomodir perseorangan atau kelompok masyarakat sebagai pemohon perkara usul pembubaran partai politik. Selain itu perlu ditambahkan satu ayat yang mengatur tentang kewajiban para pemohon untuk melampirkan bukti berupa putusan pengadilan yang telah berkekuatan hukum tetap (inkracht) terhadap pelanggaran hukum yang dilakukan oleh partai politik. Bagi Partai politik agar dapat menjalankan visi, misi dan tujuan sesuai koridor hukum yang berlaku. Dan bagi masyarakat agar lebih proaktif dalam melakukan pengawasan terhadap partai politik. 


\section{Daftar Pustaka}

Ali Safa'at, Muchamad, Pembubaran Partai Politik Pengaturan dan Praktik Pembubaran Partai Politik dalam Pergulatan Republik, Rajawali Press, Jakarta, 2011.

Asshiddiqie, Jimly, Kemerdekaan Berserikat Pembubaran Partai Politik dan Mahkamah Konstitusi, Konstitusi Press, Jakarta, 2005.

, Hukum Tata Negara Darurat, Rajawali Press, Jakarta, 2008.

, Konstitusi dan Konstitusionalisme Indonesia, Cet 2. Jakarta, Sinar Grafika Offset, 2011.

, Pengantar Ilmu Hukum Tata Negara, Cet 3, Rajawali Press, Jakarta, 2011.

Budiardjo, Miriam, Dasar-Dasar Ilmu Politik, PT Grafika Pustaka Utama, Jakarta, 2008.

Gaffar, Affan, Politik Indonesia Transisi Menuju Demokrasi, Pustaka Pelajar, Yogyakarta, 1999.

Huda, Ni'matul, Hukum Tata Negara Indonesia, PT Raja Grafindo Persada, Jakarta, 2006.

J. Prihatmoko, Joko, Mendemokratiskan PEMILU Dari Sistem Sampai Elemen Teknis, Pustaka Pelajar, Yogyakarta, 2008.

Manan, Bagir, “Kedaulatan Rakyat, Hak Asasi Manusia dan Negara Hukum”, dalam Jurnal Konstitusi PSHK-FH Universitas Islam Indonesia., Vol. IV No. 2, November 2011.

Marbun, S.F., Peradilan Administrasi Negara dan Upaya Administratif Di Indonesia, FH UII Press, Yogyakarta, 2011.

Soehino, Ilmu Negara. Yogyakarta, Liberty, Yogyakarta, 2004.

Undang-undang Nomor 2 Tahun 2008 jo Undang-Undang Nomor 2 Tahun 2011 tentang Partai Politik.

Undang-Undang Nomor 24 Tahun 2003 jo.Undang-Undang Nomor 8 Tahun 2011 tentang Mahkamah Konstitusi.

Putusan Mahkamah Konstitusi No. 53/PUU-IX/2011

http://www.antikorupsi.org/id/content/parpol-tak-lepas-dari-jerat-korupsi.[1 Juni 2013]

http:/ / www.beritaonline.web.id/2013/03/partai-politik-paling-korup-menurutlembaga-survei.html. [1 Juni 2013]

http://adedidikirawan.wordpress.com/teori-negara-hukum-rechtstaat/[10 Juni 2013]

http:/ / www.us-rs.si/en/about-the-court/legal-basis/statutes/constitutional-courtact/viii-deciding-on-the-unconstitutionality-of-the-ac/ [24 juni 2013] 